JURNAL KOMUNIKASI DAN BISNIS

VOLUME VII NO.2 NOVEMBER 2019

ISSN 2355-5181

\title{
MEMAHAMI BIROKRAT SEBAGAI PELAYAN PUBLIK DALAM TINJAUAN KOMUNIKASI ORGANISASI
}

\begin{abstract}
Ira Lusiawati ${ }^{1}$
Abstract

It is no longer a publik secret if in Indonesia from the beginning until now it always faces serious obstacles from the bureaucracy. The attitude and behavior of bureaucrats also greatly affect the implementation of tasks in accordance with the existing situation. In many cases, the attitude of the bureaucrat will influence its behavior. There are three types bureaucrats: operator, manager and executive. Executive behavior in the local publik bureaucracy in Indonesia has experienced significant changes, especially in recruiting new employees, is also very much influenced by family law. This means that employee recruitment is intended to accommodate family, relatives or friends with a certain amount of reward. Executive behavior that always wants to add subordinates. Organizational communication becomes important when the behavior of bureaucrats adopts and spreads new values in the organization, especially the organization in providing services to the publik.
\end{abstract}

Keywords: Organization Communication, Publik Bureaucracy, Bureaucratic Behavior.

\begin{abstract}
Abstrak
Bukan lagi rahasia umum jika di Indonesia dari dulu hingga saat ini selalu menghadapi hambatan serius dari birokrasi. Sikap dan perilaku birokrat juga sangat mempengaruhi pelaksanaan tugas sesuai dengan situasi yang ada. Pada banyak kasus, sikap birokrat akan mempengaruhi perilakunya. Terdapat tiga tipe birokrat, yaitu operator, manajer dan eksekutif. Perilaku eksekutif di birokrasi publik daerah di Indonesia mengalami perubahan signifikan terutama dalam merekrut pegawai baru, sangat diwarnai hukum keluarga. Artinya rekrutmen pegawai ditujukan untuk mengakomodasi keluarga, saudara atau teman dengan jumlah imbalan tertentu. Perilaku eksekutif yang selalu ingin menambah bawahan. Komunikasi organisasi menjadi penting manakala perilaku birokrat mengadopsi dan menyebarkan nilai-nilai baru dalam organisasi, khususnya organisasi dalam memberikan layanan kepada publik.
\end{abstract}

Kata kunci: Komunikasi Organisasi, Birokrasi Publik, Perilaku Birokrasi.

\section{PENDAHULUAN}

Indonesia merupakan negara yang selalu mengalami hambatan mengenai birokrasi. Misalnya saja Kejaksaan, kepolisian dan pengadilan mengalami kelambanan dalam kerja dan moralitas sehingga berdamak pada reputasi dan mengalami krisis kepercayaan. Selain itu, lambannya birokrasi perijinan menyebabkan minimnya investasi yang masuk ke Indonesia.

\footnotetext{
${ }^{1}$ Penulis adalah Kandidat Doktor Dalam Bidang Ilmu sosial pada Universitas Pasundan Bandung. Penulis untuk korespondensi: Email:iralusiawati@yahoo.co.id
} 


\section{JURNAL KOMUNIKASI DAN BISNIS}

$\begin{array}{ccc}\text { Rumitnya } & \text { birokrasi di Indonesia } \\ \text { menyebabkan } & \text { berbagai } & \text { permasalahan }\end{array}$ diantaranya: Pertama, birokrasi di negara berkembang seperti Indonesia sangatlah kompleks. Jumlah pegawai lebih banyak Perilaku eksekutif pada birokrasi di negaranegara berkembang mempunyai keunikan tersendiri, seusai dengan lingkungan sosial politik yang ada. Setiap pejabat negara berkeinginan untuk meningkatkan jumlah bawahannya; Mereka saling memberi kerja (yang tidak perlu). Akibatnya birokrat cenderung meningkat terus jumlah pegawainya tanpa memperhatikan tugas-tugas yang harus mereka lakukan (Evers dan Schiel, 1992).

Selain itu, nepotisme juga sangat merajalela di negara Indonesia. contohnya, bilamana ada rekruitmen pegawai maka akan diprioritaskan kepada keluarga, kerabat, teman terdekat saudara atau kawan dengan imbalan tertentu. Sehingga akan tercipta sebuah otonomi dan sistem dinasti.

Kedua, lemahnya administrative di negara berkembang. Misalnya, jika ada proses lelang maka itu hanya menjadi ajang kolusi antara birokrat dengan pengusaha. Ketiga, pembangunan birokrasi menyebabkan bias pada masyarakat miskin. Ketidaksesuaian pemerintah dalam merealisasikan model pembangunan di daerah pedesaan menyebabkan bias terhadap masyarakat miskin.

Keempat, perbedaan perilaku gender. Dalam kasus ini perempuan cenderung tidak diutamakan dalam memberikan kontribusi dalam pembangunan. Secara umum partisipasi perempuan dalam birokrasi relative sangat rendah. Di Indonesia perempuan yang menempati jabatan eselon satu sector publik kurang dari satu persen. Dalam perspektif ini, birokrasi tidak lagi merefleksikan nilai rasional sebagaimana dicetuskan Weber. Oleh karena dominasi pria dalam birokrasi menjadikan birokrasi sebagai representasi kepentingan mereka.

Kelima, birokrat disalahgunakan untuk kepentingan pribadi. Misalnya penggunaan dibandingkan dengan hasil kinerja serta layanan yang kecil. Jika dibandingkan dengan negara maju yang mana jumlah pegawai negeri 6 banding 100 orang penduduk.

sumber daya publik dengan memasukan anggota keluarga yang tidak memenuhi persyaratan untuk masuk ke dalam pekerjaan publik, menjual asset negara, dan membayar perantara untuk membuat paspor cepat.

Kelima permasalahan diatas sangat erat kaitannya dengan perilaku birokrat itu sendiri. Sesungguhnya apa saja faktor yang mendorong perilaku birokrat di Indonesia sebagai pelayan publik? Bagaimana perilaku birokrat kaitannya dengan komunikasi dan budaya organisasi? Mengapa birokrat memiliki perilaku-perilaku yang khas? Semua itu akan dibahas secara mendalam melalui pemaparan pada makalah berikut ini.

\section{KAJIAN PUSTAKA}

Istilah birokrasi berasal dari kata bureaumania, yang mengacu kepada suatu penyakit yang melanda pemerintahan ditandai dengan penyimpangan dalam menjalankan wewenang, yang seharusnya melayani publik / masyarakat, namun justru untuk kepentingan pribadi. Hal ini biasanya dikeluhkan dengan pejabat, juru ketik, para sekretaris, para inspektur dan para intendan yang diangkat bukannya untuk menguntungkan kepentingan umum, bahkan kepentingan umum itu nampak karena adanya para pejabat. Istilah bureau diartikan meja tulis atau suatu tempat pejabat bekerja, dan dalam kamus Akademi Perancis pada tahun 1798 diartikan sebagai: "kekuasaan dan pengaruh dari para kepala dan staf biro pemerintahan" (Albrow, 1996).

Konsep birokrasi yang digagas oleh Weber hingga kini masih menjadi referensi. Meskipun hal itu tidak lepas ari kritikan cendekiawan lainnya. hal itu mengacu kepada negara, gereja, dan partai politik, yang memiliki tatanan hubungan-hubungan sosial, di mana 


\section{JURNAL KOMUNIKASI DAN BISNIS}

para anggota organisasi didalamnya memiliki tugas-tugas spesifik dan struktur hierarkis.

Pada dasarnya pemimpin diperlukan untuk memimpin dan mengatur sebuah organisasi. Dalam kaitannya dengan organisasi, maka diperlukan semacam aturan untuk mengatur tingkah laku manusia. Aturan pada dasarnya merupakan konsep yang hakiki dari organisasi, yang mana terdiri dari aturan yang bersifat organisasional dan nonorganisasional. Dalam sebuah negara yang sudah modern diperlukan suatu badan administrasi yang dikelola oleh apparat yang diangkat dan dinamakan birokrasi (Weber).

Pemikiran Weber ini sangat berpengaruh pada filosofi dan pengelolaan birokrasi publik hingga kini di seluruh dunia. Model hirarki, profesionalitas, dan sistem merit adalah prinsipprinisp umum organisasi modern yang diterapkan pada birokrasi publik, termasuk juga di Indonesia. Nilai yang dijunjung tinggi pada tipologi birokrasi Weber ini adalah rasionalitas dan efisiensi (Williamson, 1990).

Dengan demikian, birokrasi publik harus mengejar nilai efisiensi dan profesionalitas dalam penyelenggaraan tugasnya, termasuk pelayanan kepada masyarakat. Dalam sudut pandang ini, kesuksesan pelayanan oleh birokrasi publik dinilai dari pencapaian efisiensinya. Budaya organisasi sebenarnya merupakan sistem tindakan yang berbeda dalam organisasi yang telah terpola dalam mengarahkannya untuk menanggapi rangsangan dari luar dengan cara yang berbeda (Wilson, 1989 dalam Dwiyanto, 2012).

Weber merupakan sorang filsuf yang memfokuskan perhatian yang sangat besar terhadap tindakan manusia untuk mencapai tujuan secara rasional. Teori yang dikemukakan Weber sangat sering digunakan dalam kajian komunikasi organisasi. Ia memberikan gagasan klasik mengenai struktur organisasi yang bersifat hierarkis serta dikontrol aturan.

Meskipun teori Weber tidak mengkhususkan membahas mengenai komunikasi, akan tetapi pandangannya mampu meletakan dasar-dasar asumsi yang kuat serta memengaruhi para ahli dalam menggambarkan serta menjelaskan tentang komunikasi organisasi. Weber mendefinisikan organisasi sebagai suatu sistem kegiatan komunikasi antar pribadi dalam organisasi yang bertujuan yang dirancang untuk mengkoordinasikan tugas individu.

Adapun perbedaan birokrasi dan kelompok yaitu terdapat pada birokrasinya. Sebuah organisasi diatur dan diikat oleh birokrasi. Birokrasi yang dicetuskan oleh Weber bertujuan utuk menemukan solusi dalam mengindari perilaku tercela, seperti korupsi, ketidakadilan, serta nepotisme yang saat ini marak terjadi pada organisasi modern.

Sistem tindakan yang terpola dalam menghadapi warganegara antara organisasi pemerintah satu dengan yang lain akan berbeda sesuai dengan budaya organisasinya. Pada organisasi yang patrimonial, pola pelayanan akan sangat berorientasi pada pelayan dan bukan pada pelanggan. Yang menarik selain, secara internal budaya organisasi mempengaruhi sikap dan perilaku birokrat, tetapi juga lingkungan politik yang melingkupinya (Schein, 1992).

Perilaku kelompok adalah salah satu aspek budaya organisasi, termasuk pertama, birokrasi publik yang menjadi fokus makalah ini. Kedua, norma kelompok yang berupa standard dan nilai implisit dalam kelompok. misalnya, pejabat senior yang menerima honor lebih besar atau eselon golongan tinggi menerima honor lebih tinggi dan seterusnya. Ketiga, budaya organisasi dapat pula berupa nilai yang diartikulasikan, seperti birokrasi pemerintah berusaha mengartikulasikan nilai pelayanan prima.

Filosofi yang bersifat resmi biasanya dinyatakan dalam dokumen perencanaan organisasi. Misalnya, polisi merupakan pelayan dan pelindung masyarakat. Filosofi polisi seperti apa yang dikatakan oleh Mantan Kapolri yakni "Polisi merupakan sekumpulan orang yang baik". Dalam hal ini para polisi ini memiliki filosofi budaya berupa aturan main, biasanya 


\section{JURNAL KOMUNIKASI DAN BISNIS}

mengacu kepada aturan main implisit. Misalnya prosedur bagi anggota baru yang masuk dalam suatu lingkup birokrasi publik.

Wilson (dalam Dwiyanto, 2012) menyebutkan ada tiga faktor yang mempengaruhi perilaku ini yaitu sikap anggotanya, teknologi organisasi dan tindakantindakan penting yang dilakukan pada situasi tertentu. Pembahasan sikap dan perilaku anggota birokrasi pelayanan publik secara empiris cukup langka dilakukan oleh para ahli, terutama di Indonesia. Bagaimana perilaku birokrasi ditinjau dari komunikasi organisasional maupun secara individual dalam suatu sistem politik tertentu. Jika kajian ini dilakukan maka pendekatan interdisipliner keilmuan harus digunakan untuk menjelaskan dan memahami perilaku birokrat di negara berkembang.

Wilson dalam hal ini membagi tiga kategori birokrat dalam organisasi pemerintah, yang pertama operator, kedua manajer dan ketiga eksekutif. Wilson berusaha menggambarkan perilaku tiga jenis birokrat tersebut dalam melaksanakan tugas-tugas kesehariannya. Operator yang dimaksud oleh Wilson adalah birokrat yang bertugas di bagian garda depan organisasi yang berhadapan langsung dengan masyarakat dan masalah

Pertama, birokrat tipe operator. Operator didefinisikan sebagai bagian dari birokrat namun posisinya berada di bawah dan berhadapan serta melayani masyarakat secara langsung. untuk memahami organisasi publik pertama-tama yang harus dilakukan adalah melihat pelayanan garisan paling depan, sebeb organisasi publik ini memiliki goal yang kurang jelas. Hal itu dapat dilihat dari visi birokrasi pelayanan publik itu sendiri. Misalnya, visi Dinas Pendidikan adalah tercapainya masyarakat yang cerdas. Dinas Pertanian memiliki visi tercapainya kesejahteraan petani.

Selain itu, sikap dan perilaku birokrat pun sangat mempengaruhi pelaksanaan tugas sesuai dengan situasi yang ada. Hal itu dapat terlihat dari sikap birokrat yang akan mempengaruhi perilakunya. Misalnya saja, tentang sikap rasial polisi. Sebagian polisi yang berkulit putih mempunyai sikap rasial dan bahkan fanatik, namun pada saat mereka menangkap tersangka kejahatan sikap tersebut tidak mempengaruhi perilakunya. Point penting yang diperhatikan adalah mungkin organisasi merubah perilaku anggotanya tanpa merubah sikapnya. Sebaliknya perlakuan sistem reward dan hukuman ternyata efektif merubah perilaku.

Tugas birokrat sering mengacu pada pengalaman pertama kali mereka bekerja. Organisasi yang baru terbentuk biasanya merekrut pegawai dari berbagai instansi, biasanya mereka mendefinisikan tugas pada pengalaman pertamanya. Pengalaman dari pekerjaan sebelumnya akang sangat memepengaruhi mereka dalam mengemban tugas di organisasi barunya.

Mereka mendefinisikan tugasnya lebih pada standard kelompok acuan dari pada manajemen internal. Apakah tidak sebaliknya kaum profesional justru mengikuti budaya birokrasi publik yang ada dan justru tidak membawa perubahan? Banyak kaum profesional memberikan justifikasi pada tradisi birokrasi yang lama. Sikap aparat dalam memberikan pelayanan kepada masyarakat sangat tergantung kepada sikap mereka pada evaluasi sejauh mana reward dan punishment yang diperoleh dari tindakan yang dilakukan (Dwiyanto, 2012).

Dengan demikian, apakah setiap pelayanan yang diberikan kepada masyarakat akan diberikan ganjaran baik moral maupun materi. Dan sebaliknya, ketika aparat akan mendapatkan hukuman maka mereka akan menghindarinya. Reward bagi birokrat lebih banyak bersifat nonmaterial yang mencakup tiga jenis, yaitu perasaan dalam menjalankan tugas, status dan kekuasaan serta keuntungan yang di dapat dalam berorganisasi.

\section{HASIL PENELITIAN DAN PEMBAHASAN}

Pada sebuah penelitian yang berhubungan dengan birokrasi pelayanan social ditemukan 


\section{JURNAL KOMUNIKASI DAN BISNIS}

bahwa perilaku aparat bergantung kepada sikap dari orang yang dilayaninya. Jika kliennya banyak menuntut, agresif, dan banyak mengetahui tentang pelayanan, maka sikap apparat kurang responsive. Namun sebaliknyam jika klien yang dihadapi kooperatif dan tidak banyak menuntut makan sikap apparat pun cenderung responsive.

Pada kasus diatas, pelaku birokrat di tingkat bawah akan menghindar jika situasi yang dihadapinya agresif dan banyak menuntut. Begitu juga sebaliknya, mereka akan lebih renponsif dan ramah pada klien yang kurang menuntut. Hal ini tentu saja bahwa sikap responsive pada birokrat kurang mendapat penghargaan yang lebih baik. Begitu juga sikap kurang responsive yang tidak mendapatkan hukuman.

Menurut Nurmandi (2005) ideologi politik pun sangat mempengaruhi sikap dan perilaku birokrat. Dalam kasus birokrasi di Indonesia, ideologi politik yang telah tertanam sejak lama adalah ideologi pembangunan dan ketertiban. Substansinya adalah memandang suatu kehidupan politik tanpa ideologi adalah sama dengan memandang suatu masyarakat tanpa konflik. Kehidupan politik tanpa ideology juga menunjukkan bahwa adanya suatu bangsa tanpa harapan suatu keadaan yang tidak akan ditemukan dalam masyarakat kontemporer manapun, apalagi dalam suatu negara baru seperti Indonesia (Liddle, dalam Mas'oed, 1989:132).

Terkait tugasnya, birokrat sangat dipengaruhi oleh kepribadian. Dalam organisasi yang besar dan kompleks. Birokrat tipe operator pada prinsipnya lebih menghargai cara bekerja daripada tujuan dan mereka lebih mengikuti peraturan yang benar daripada mencapai tujuan organisasi, yang disebutnya sebagai "goal displacement", dimana nilai-nilai instrumental menjadi nilai-nilai terminal (antara). Goal displacement adalah pengalihan tujuan organisasi publik dari goal yang sebenarnya. Misalnya, tujuan Dinas Tata Kota adalah mengendalikan penggunaan tanah di wilayah tertentu, namun beralih menjadi penggalian dana dari masyarakat dengan menggalakkan pemberian atau pemutihan Ijin Mendirikan Bangunan (IMB). Karena semakin banyak IMB semakin besar pula pendapatan asli daerah yang dapat diperoleh.

Kedua, birokrat tipe manajer. Birokrat tipe ini berfokus pada pengelolaan organisasi dari hambatan-hambatan lingkungan. Misalnya lingkungan dunia politik. Bagi birokrasi publik, politik menjadi sangat tidak pasti dan perlu dikelola sedemikian rupa agar tidak merugikan organisasi.

Pada hakikatnya, organisasi pemerintah mask uke dalam empat jenis lingkungan politik, yaitu pertama, terdapat satu kelompok kepentingan yang mendukung organisasi pemerintah. Kedua, terdapat satu kelompok kepentingan yang mengorbankan tujuan. Ketiga, terdapat dua atau lebih kelompok kepentingan yang konflik satu sama lain terhadap tujuan. Dan terakhir, tidak ada kelompok kepentingan yang penting. Dalam kondisi pertama, organisasi pemerintah merupakan hasil dari politik klien, di mana benefit mempunyai nilai per kapita tinggi dan nilai biaya per capita rendah. Keuntungan hanya dinikmati oleh sekompok kepentingan sedangkan biaya dibebankan pada sebagian besar masyarakat. Kondisi sebaliknya merupakan entreprteneurial politics, yang mana biaya dibebankan pada sejumlah industri, profesi atau daerah tetapi keuntungan dinikmati oleh banyak pihak.

Begitu juga dengan instansi pemerintahan, yang dipengaruhi oleh kelompok kepentingan baik kepentingan klien maupun kepentingan lawan. jika hadiah atau reward yang diterima lebih banyak dan memenuhi kepentingan klien, disinilah para birokrat akan membela sang klien. Dengan demikian, para birokrat ini sesungguhnya hanya mementingkan dirinya pribadi.

Setiap organisasi memiliki sebuah budaya, dimana setiap individu dalam organisasi memiliki kebiasaan dan tindak tutur yang khas yang menjadi acuan untuk menjalankan 


\section{JURNAL KOMUNIKASI DAN BISNIS}

aktivitasnya. Keterkaitan antara tindakan birokrat dalam organisasi, perilaku komunikasinya dan budaya ini dikonseptualisasikan sebagai berikut; pertama, tugas birokrat yang bukan merupakan bagian dari budaya organisasi tidak akan mengemuka dan tidak akan terkomunikasikan. Kedua, organisasi yang mempunyai dua atau lebih budaya akan mengalami benturan antara satu dengan bagian lainnya; Ketiga, organisasi akan resisten terhadap nilai-nilai baru serta tugas baru jika tidak sesuai dengan budaya dominannya (Schein, 1992).

Misalnya, kita dapat melihat hal itu pada kasus pemalsuan uang yang malah dilakukan oleh salah seorang pejabat Badan Intelijen Negara bidang Pemalsuan Uang dan dilakukan di Kantor Badan Intelijen Negara (BIN) Indonesia 15 tahun silam menunjukkan bahwa budaya organisasi yang ada lebih dipengaruhi oleh budaya birokrasi Orde Baru daripada harus mengadopsi tugas baru yang lebih penting yakni menjaga keamanan negara. Selain itu banyak kasus pengeboman dan pemalsuan uang tidak dapat diantisipasi oleh BIN.

Mengacu pada undang-undang seleksi penerimaan pegawai negeri atau aparatur sipil Negara, perekrutan dilakukan dengan berdasarkan sistem merit, yakni kebijakan dan manajemen aparatur sipil negara berdasarkan pada kualifikasi, kompetensi, dan kinerja secara adil dan wajar tanpa membedakan faktor politik, ras, agama, asal usul, jenis kelamin, dan kondisi kecacatan. Hamun realitasnya sangat mudah untuk dilanggar dan sistem seleksi kepegawaian saat ini sangat semrawut dan penuh dengan perilaku KKN.

Sistem pengelolaan sumber daya manusia di ranah birokrasi publik sangat berbeda jauh dengan birokrasi di swasta. Misalnya saja, penggolongan, kinerja, bonus dan sistem penggajian yang tidak berkait dengan kinerja organisasi. Selain itu pencopotan pegawai negeri sivil (PNS) yang sangat susah dan memakan waktu lama. Dengan demikian, nyatalah bahwa terjadi kebobrokan dalam pengelolaan SDM di ranah birokrasi pemerintah. Berbagai permasalahan publik yang dihadapi oleh birokrasi publik di Indonesia saat ini merupakan ineefesiensi, kesenjangan akuntabilitas, maraknya korupsi serta ketidakadilan pelayanan dalam masyarakat. Sulitnya menerapkan efisiensi pada struktur birokrasi dan hierarki publik. Sebab banyak hambatan dalam meningkatkan keefisiensian di dalam Lembaga pemerintahan. Dengan demikian, pemahaman dan pengetahuan dalam melaksanakan komunikasi organisasi yang tepat sangat perlu untuk direalisasikan. Komunikasi organisasi yang meliputi penyampaian arus informasi yang tepat, mendukung iklim komunikasi yang sehat serta menciptakan rasa kepuasan dalam berkomunikasi dan birokrasi sangat dibutuhkan.

\section{KESIMPULAN}

Penjelasan teoritis tentang bagaimana perilaku para birokrat mulai dari tingkat atas atau atasan hingga tingkat bawah atau bawahan didapatkan beberapa kesimpulan berikut ini, yaitu: terdapat tiga tipe birokrat publik yaitu pertama operator, kedua manajer dan terakhir eksekutif dan ketiganya memiliki perilaku yang berbeda-beda. Adapun perilaku ketiga birokrat tersebut selalu bersifat rasional dalam menentukan serta menjaga pilihannya. Perilaku para birokrat tersebut sebetulnya sangat dipengaruhi oleh perilaku eksekutifnya terutama mengenai budaya organisasi yang sebetulnya merupakan kekuatan dan kelemananya dalam menjalin hubungan dengan pihak atau klien di luar.

Perilaku birokrat sebetulnya tidak terlepas dari komunikasi organisasi, dan komuniaksi organisasi tersebut menjadi sangat penting bagi para birokrat. Di mana komunikasi organisasi dapat membantu menyebarkan nilainilai baik yang lama maupun yang baru dalam organisasi, khususnya organisasi dalam memberikan layanan kepada publik. Dalam 


\section{JURNAL KOMUNIKASI DAN BISNIS}

kaitanya dengan pelayanan, masih sering kali ditemui sikap kurang responsive bilamana menghadapi klien yang agresif dan kritis. Perilaku para birokrat pada masa reformasi ini sebetulnya masih dipengaruhi oleh perilaku birokrat pada masa orde baru.

\section{DAFTAR PUSTAKA}

Albrow, M (1996). Bureacracy, $1^{\text {st }}$ Edition, New York:The Free Press.

Dwiyanto, A. Dkk (2012), Reformasi Birokrasi Publik di Indonesia, Pusat Studi Kependudukan dan Kebijakan-UGM, Cetakan Kedua, Jogyakarta: UGM Pers.

Evers, H.D. dan Schiel, T. (1992), Kelompokkelompok Strategis, Studi Perbandingan tentang Negara, Birokrasi dan Pembentukan Kelas di Dunia Ketiga,
Edisi Terjemahan, Jakarta : Yayasan Obor.

Mas'oed, M. (1989), Ekonomi dan Struktur Politik Orde Baru 1966-1967, Cetakan Pertama, Jakarta:LP3ES.

Nurmandi, A. (2005), Perilaku Birokrasi Publik di Indonesia: Sebuah Kajian Teoritis, Jurnal Sosiohumaniora, Vol.7 No.2, pp : 143-157, Universitas Padjadjaran, ISSN : $1411-0911$.

Williamson, O. E. (ed) (1990), Theory Organization From Chester Barnard to the Present and Beyond, Oxford: The Oxford University Press.

Schein, E. H. (1992), Organizational Culture and Leadership, San Francisco : Jossey Bass Publisher. 